чаще встрђчағщимисл при гервомъ аномаліями въ аппарат'ь кровообращенія.

9) Неправильности развитія плода и патологическія состоянія его несравненно чаще встрбчаются шри двойняхъ изъ одного яйца, чьмъ изъ 2 -хъ. Посльдніе не представляють въ этомъ отнопеніи разницы отъ беременныхъ однимъ плодомъ.

10) Насльвдственность по отношенію двойней повидимому касается только происхожденія изъ $2 \cdot \mathbf{x ъ}$ япцъ.

На двушлодную берем. изъ 2-хъ яищъ авторъ смотритъ какъ на нормальное явлевіе, двуплодную же берем. изъ 1-го яйца овъ считаетъ явленіемъ патологическимъ; основанія для этого онъ видитъ въ. крайней ихъ рьдљости (1 на 600, 700 родовъ), болье ранній и болье поздній возрастъ рождающихъ, иногда отсутствіе одного amnion'a, большое число нецравильностей плода, большая разница въ развитіи обопхъ плодовъ, чрезмњрно большое и чрезмърно малое количество водъ, частая внутриутробная смерть одного плода и наконецъ очень рыдкая насльдственность.

\title{
Б. Фраткинъ.
}

58. Wendel. Ein Beitrag zur Lehre vom Kindesmorde. (Inaug. diss. Dorpat. 1892). Къ ученію о дьтоубійствђ.

На основаніи матерьяла $71-91$ судебно-медицинскихь вскрытій новорожденныхъ въ разныхъ періодахъ, произведенныхъ проф. Керберомг въ Дерпт'ь, авторь приходить къ сльдующимъ выводанъ относительно признаковь новорожденности, зрьлости ребенка внь утробной жизни и причины смерти: 1) Загрязненіе кожи первороднымъ каломъ, кровью, сыровидною смазкою, какъ цризнаки новорожденности, встръчались по чисто мьстнымъ условіямъ сравнительно рьдко, чаще можно было найти сыровидную смазку въ локтевыхъ п паховыхъ складкахъ. Пуповина (остатокъ) большею частью оказывалась не перевязанои, а какь бы оборванной. 2) Средняя длина зрьлыхъ поворожденныхъ 50,8, высъ-средніі 2778. Малый средній вьсъ доношенныхъ новорожденныхъ незаконныхъ, авторъ объясняетъ "главнымъ образомъ психическшмъ состояніемъ подобных'ъ беременныхъ, оказывающимъ несомнынно вліяніе на питаніе плода. Кь тому же эстонскія новорожденныя вообще меньше по въсу. Но автору приходится еще принять во вниманіе уменьпеніе въ въсь всльдствіе высыханія трушиковъ. 3) Средняя вөличина костнаго ядра (въ нижней части энифнза бедра) $5,4 \mathrm{~mm}$., minimum 0,5 mm., maximum $9 \mathrm{~mm}$. По Wendel'ю величина костнаго ядра болье $5 \mathrm{~mm}$. за малыми псключеніями соотвБтствуетьь длинь плода болье 50 сант. Но кромь этого соотвњтствія онъ отрицаеть всь остальныя, приписываемыя извђстной вөличинь лдра. 4) Самымъ главнымъ признакомъ вньутробной жизни плода-легочная проба, при чемъ приходится прпнимать вь соображеніе и другія измьненія въ легкихъ: объемъ, цвЂтъ, консистенція, содержаніе крови, поверхноссь разрьза. Изъ его матерьяла, только въ $31,1^{\%}$ о легкія содержали воздухъ на столько, что отдВльныя мелкія части плавали, во всъхъ же остальныхъ случалхъ большіе или меньшіе участки легкихъ были безвоздушны; въ 10,5\% проба лсгкихъ дала отрицательный результатъ. 0тличіе воздухосодержащихъ 
легкихъ оть пдавающихъ на воды всльдствіе развитія гніющихъ газовъ заключается въ томь, что посльднія можно заставить погрузиться наколом' видимыхъ гнилостныхъ пузырьковъ и выдавливаніемъ изъ нихъ воздуха. Крайне интересенъ приводимый авторомъ случай, при 11 часовой жизни ребенка и несомньнныхъ признакахъ, хотя слабаго, дыханія. Іроба легкаго оказалась отрицательной. Wendel объясняеть это явленіе такимъ образомъ, что при медленномь умираніи, легкое потеряло большую часть воздүха, такъ какь ребенокъ экспирироваль больше воздүха, чьыъ инспирироваль. (Јегкія могли стать безвоздушными всльдствіе всасыванія воздуха въ самихъ легкихъ, какъ объясняеть Ungar. Peфб.). 5) 0 пробь Breslau (плаваніе желудка и кишекъ) авторь отзывается, какь о хоропемъ вспомогательномъ способь для огредьленія вньутробной жизни ребенка п до нькоторой степени ея продолжительности (чьмь дальше по кишечному тракту расщространяется воздухъ, тьмъ додьще жиль ребенокъ по рожденіп); она въ исключительныхъ случаяхъ на свъжихъ трупикахъ, при отрицательной легочной пробь можеть съ громадною вњроятностью одна указать на рожденіе ребенка живымъ. У недоношенныхъ дытей сравнительно часто проба Breslau получалась положптельная при отрицательной легочной пробь. 6) Причина наси.льственной смерти ( у доношенныхъ дытей) чаще всего задушеніе одно или съ различнаго рода поврежденіями черепа; задушеніе посредствомь закрытія наружныхь воздухоносныхъ отверстій мягкими предметами 33 ;-въ $9,5 \%$ удавленіе; задушеніе посредствомь введенія пальца въ ротъ; одинъ задушенъ введеніемъ комка соломы въ зҺвъ; трое задохлись въ фекадьныхъ массахъ, изъ нихъ двое брошены въ отхожее мьсто, а 3-й упаль туда при быстрыхъ родахъ въ отхожень мьсть; двое зарыты въ землю живыми, у одного изъ нихъ, зарытаго въ песчаномъ грунть, песчинки найдены въ нижнихъ в0здухоносныхъ путяхъ. Затьмъ идуть причины смерти: кровоизліянія въ ткань мозга съ раненіемь qерепа или безъ него, недостатокь ухода, вліяніе холода. Двое умерлп оть кровотеченія: одинъ изъ разрьза черепныхъ покрововъ, прннятыхь акушеркой за плодный пузырь, другой изь нешеревязанной пуповин, отрьзанной у самого пүпочнаго кольца. Говоря о наспльственныхъ поврежденіяхъ черепа, Wendel приводить на основаніи его матерьяла отличптельнымъ признаконь подобныхъ трещинъ оть пропзвольныхъ, бывающихъ нногда при быстрыхъ родахъ и значительной тонкости черепныхъ костей съ одновременнымъ дефектомъ въ окостеньніп,-отсутствіе при посльднихъ поврежденіяхъ черепныхъ покрововъ иногда надкостницы, твердой и даже мягкой мозговыхъ оболочекъ и ихь расшоложеніе. Произвольныя находятся въ видь гуслей всегда въ темянныхъ костяхъ и идуть отъ стрьловиднаго пва къ темянному бугру, в'ъ псключнтельныхъ только случаяхъ бывають въ затылочной кости отъ дамо́довиднаго шва къ затылочной чешуь. Кровопзліянія въ полости черепа не насильственныя могуть быть также при быстрыхь родах'ь, но тогда отсутствують сказанныя поврежденія черепныхь шокрововъ и другія. Насчеть посмертныхъ нвленій авторъ въ $80 \%$ нашель подплевральные и подпернкардіальные әкхимозы; особеннаго діагностическаго значенія сами по себь они не имьютъ. 0чень интересны казуистическіө случап. 